\title{
A CASE OF VARIABLE IMPOVERISHMENT IN EUROPEAN PORTUGUESE
}

\author{
Pilar BARBOSA \\ Universidade do Minho (CEHUM/ILCH \\ Telma FREIRE \\ Universidade do Minho (CEHUM/ILCH)
}

\begin{abstract}
This paper presents a case of variable agreement leveling in European Portuguese which is found in a particular region in Portugal and has a highly restricted distribution: it only occurs in contexts with the inflected infinitive and the future subjunctive. We present the results of a series of grammaticality judgement tests and one self-paced reading test applied to the speakers of the relevant dialect that indicate that the phenomenon in question does not affect the Person features and does not pertain to narrow syntax. We propose an analysis that relies on the idea that agreement leveling is due to operations that take place in the post-syntactic PF branch of the grammar. Our approach adopts NEVINS and PARROTT'S (2010) suggestion of using the notion of 'variable rule' from Variationist Sociolinguistics (LABOV 1969) as a mechanism within the Distributed Morphology framework. (HALLE and MARANTZ 1993) to explain inter and intra-individual variation. Agreement leveling in the dialect in question is argued to be due to the probabilistic application of a rule of Impoverishment that deletes the feature [Plural] from Agr morphemes positively specified for this feature in the context of the inflected infinitive and future subjunctive. Since what these two environments have in common is the phonological shape of the exponent for $T($ ense), the affix $-r$, this is a case of inwards-sensitive phonologically conditioned Impoverishment, as predicted under the assumption that Vocabulary Insertion proceeds cyclically, root-outwards (BOBALIJK 2000).
\end{abstract}

\section{KEYWORDS}

distributed morphology, variationist sociolinguistics, Portuguese, variation, variable rule, impoverishment, agreement leveling, inflected infinitive

(C) Revista da ABRALIN, v.13, n.2, p. 185-223, jun./dez. 2014 


\section{RESUMO}

Este artigo estuda um caso de concordância variável em português europen que se verifica numa área circunscrita do Norte de Portugal e tem uma distribuição particular: apenas afeta as formas verbais de Infinitivo Flexionado e do Futuro do Conjuntivo. Apresentam-se os resultados de um série de testes de gramaticalidade e um teste de leitura automonitorizada aplicados a falantes do dialeto relevante, que indicam que o fenómeno em causa não afeta os traços de Pessoa e não pertence à sintaxe estrita. Propõe-se uma análise baseada na ideia de que a neutralização dos traços de concordância é o resultado de operações que se aplicam no nivel pós-sintáctico da gramática. A abordagem adota a proposta de NEVINS e PARROTT (2010), que usa a noção de "regra variável" da Sociolinguística Variacionista (LABOV 1969) enquanto mecanismo enquadrado no modelo da Morfologia Distribuida (HALLE e MARANTZ 1993), como forma de explicar a variação inter e intraindividual. A neutralização da concordância verbal deve-se à aplicação probabilística de uma regra de Empobrecimento que elimina o traço [Plural] dos morfemas de concordância positivamente especificados para este traço. Uma vez que o que os contextos de Infinitivo Flexionado e de Futuro do Conjuntivo têm em comum é o seu expoente, o afixo / - r/, a regra de Empobrecimento deve ser capaz de "ver" a forma do item vocabular inserido no nó T, o que vem confirmar a posição defendida em BOBALIJK 2000 segundo a qual a Inserção Vocabular procede sequencialmente, de baixo para cima.

\section{PALAVRAS-CHAVE}

infinitivo flexionado, empobrecimento, morfologia distribuida, sociolinguistica variacionista, português, regra variável, variação

\section{Introduction}

Verbal agreement as a variable "rule" in Portuguese has been the focus of research mainly in Brazilian Portuguese (BP) (SCHERRE 1994; SCHERRE and NARO 1998, A. RODRIGUES 2004), where the absence of overt agreement between the subject and the finite verb is attested: 
(1)

a. Nós não tinha medo de sucuri, não tinha medo de onça, não we not had.ø fear of sucuri not had.ø fear of jaguar not pensava em nada think-IMPERFECTIVE.PAST.Ø in nothing

b. Counterpart in the standard dialect

Nós não tínhamos medo de sucuri, não we not have. IMPERFECTIVE.PAST.1PL fear of sucuri not tínhamos medo de onça, não pensávamos have.IMPERFECTIVE.PAST.1PL fear of Jaguar not think.IMPERFECTIVE.PAST.1PL em nada.

in nothing

'We weren't afraid of sucuri, we weren't afraid of jaguar, we didn't think of anything.' (A. RODRIGUES 2004: 134)

In the case of European Portuguese (EP), there is no record of similar alternations. The existing studies on the topic (MOTA and VIEIRA 2008; CARDOSO, CARRILHO and PEREIRA 2012) mostly describe alternations between plural and singular agreement in co-occurrence with a plural DP subject, as illustrated in (2). These studies conclude that the type of verb (unaccusative) and the position of the subject (postverbal) are decisive factors in favor of non-standard agreement.

(2) quando morria pessoas ...
when died.3sg people

The qualitative differences between BP and EP concerning nonstandard verbal agreement are arguably related to the null subject property, EP being a consistent null subject language and hence requiring rich verbal agreement morphology (cf. BARBOSA, KATO \& DUARTE 2006) and BP, a partial null subject language (C. RODRIGUES 2004), no longer requiring rich agreement. 
The present study investigates a case of variation in verbal agreement in EP that, as far as we know, has never been described before in the literature, and has particular properties and distribution: the omission of phi-feature agreement in contexts with the inflected infinitive, as exemplified in (3b, 4b, 5b) (examples taken from spontaneous speech).

a. Standard EP

Se é para nós comermos, eu venho.

if be. Pres.Ind.3sg for we.NOM eat.Inf.1PL I come.Pres.IND.1sg 'If it is for us to eat, I'll come.'

b. Se é para nós comer, eu venho. if be. Pres.Ind.3sg for we.NOM eat.INF- $\varnothing$ I come.PrEs.IND.1sG

(4)

a. Standard EP

É melhor nós irmos lá.

be. Pres.Ind.3sg better we.NOM go.INF-1 PL there

'It is better for us to go there.'

b. É melhor nós ir lá.

be. Pres.Ind.3sg better we.NOM go.InF- $\varnothing$ there

(5)

a. Standard EP

Isto é para nós fazermos?

this be. Pres.IND.3sg for we do. INF-1 PL

b. Isto é para nós fazer?

this be. PRES.IND.3sg for we do. INF- $\varnothing$

'Is this for us to do?' 
This type of non-standard agreement is attested in a particular region in the North of Portugal — Vale do Sousa and Vale do Ave —, and is rather intriguing in view of the observation (DUARTE, GONÇALVES and SANTOS 2013) that there is a general tendency to overuse the inflected infinitive in colloquial EP (cf. (6b)) even in contexts that require the uninflected form in the standard variety (cf. (6a)):

a. Standard dialect: Eles acabam de falar com a Maria. they finish.Pres.IND.3PL of talk. INF- $\varnothing$ with the Maria 'They have just talked to Mary.'

$\begin{array}{llll}\text { b. Eles acabam de falarem com a } & \text { Maria } \\ \text { they finish. Pres.Ind.3PL of talk. INF.3PL with the } & \text { Maria }\end{array}$

This article presents the results of a battery of tests applied to the speakers from the region in question, namely grammaticality judgment tests (GJT) and a test of self-paced reading (section 2). The results show that (i) agreement leveling only affects the agreement morphemes positively specified for the feature [Number]; (ii) the phenomenon at issue is not limited to the inflected infinitive; it also extends to the future subjunctive. In section 3, we present an analysis of this phenomenon based on the notion of "variable rule" from Variationist Sociolinguistics (LABOV 1969) as a mechanism within the theory of Distributed Morphology (HALLE and MARANTZ, 1993), along the lines proposed in NEVINS and PARROT'T (2010). In particular, we suggest that the phenomenon in question is due to the application of a rule of Impoverishment in the post-syntactic level of grammar. Following NEVINS and PARRO'T'T (2010), we propose that this is a variable rule, i.e., a rule that operates in a probabilistic rather than in a deterministic fashion. Given that the inflected infinitive and the future subjunctive share the same affix, /-r/, we conclude that the Impoverishment rule 
must be able to "see" the particular lexical item inserted under T, thus corroborating the proposal originally put forward in BOBALIJK (2000) that Vocabulary Insertion proceeds cyclically, root-outwards.

\section{Experimental tasks}

The experimental tasks were conceived so as to anticipate and assess the contexts in which verbal agreement is leveled and determine whether the phenomenon in question is indeed limited to a particular region in the North of Portugal: Vale do Ave and Vale do Sousa. Two different techniques - offline and online — were used: a series of grammaticality judgment tests (GJT) and a test of self-paced reading. These tasks were presented to the participants at different stages of the investigation, as discussed in the next subsections.

\subsection{Grammaticality judgement test 1}

\section{Participants}

Study group: 50 adolescent speakers from Vale do Ave e Vale do Sousa, all currently in the second year of secondary education, average age of 16.4 .

\section{Materials}

Conditions were created to test finite and infinitival clauses. In each condition, there were standard agreement clauses and non-standard agreement clauses. In both finite and infinitival clauses, the environments tested included purpose clauses as well as clauses in subject and object (with and without preposition) position. The following examples illustrate test sentences for the condition 'purpose clause'. The two versions, with and without agreement, were presented to the subjects (the asterisk is meant to reflect the grammar of standard EP): 
(7)

a. O professor tem de ser exigente para os alunos the teacher has of be.INF demanding for the students *trabalhar / trabalharem work.INF. $\varnothing \quad / \quad$ work.INF.3PL

'The teacher must be demanding in order for the students to work.'

b. O professor tem de ser exigente para que the teacher has of be.INF demanding for that os alunos *trabalhe / trabalhem the students work.SUBJ.Ø / work.SUBJ.3PL 'The teacher must be demanding so that the students work' $\mathrm{INF}=$ infinitive SUBJ $=$ subjunctive

Regarding finite clauses, besides subordinate clauses in the present and past subjunctive, the conditions tested also included matrix indicative clauses and if and when-clauses in the future subjunctive. The main reason for including the future subjunctive was that the speakers of this region produced utterances such as $(8 \mathrm{a}-9 \mathrm{a})$ (compare these with standard EP (8b-9b))

a. Se nós acabar isto, podemos sair? if we finish.subJ.FuT. $\varnothing$ this, can. IND.PREs.IPL leave b. Standard EP

Se nós acabarmos isto, podemos sair? if we finish.subJ.FuT.1PL this, can. IND.PREs.IPL leave 'If we finish this, can we leave?'

$\begin{array}{lrrrr}\text { a. Se eles for, } & \text { eu } & \text { também } & \text { vou. } \\ \text { if } & \text { they } & \text { go SUBJ.FUT.ø, I } & \text { also } & \text { go IND.PRES.1sG }\end{array}$ 
b. Standard EP

Se eles forem, eu também vou.

if they go sUBJ.Fut.3PL I also go IND.PREs.1sG

'If they go, I also go.'

(8a) and (9a) are ungrammatical in the standard dialect. (8a) contains a regular verb and $(9 \mathrm{a})$ contains an irregular verb. This point is important given that, with regular verbs, the forms for the future subjunctive and the infinitive are homophonous whereas in the case of irregular verbs they show stem allomorphy, as shown below:

\begin{tabular}{|l|l|l|l|l|}
\hline \multirow{2}{*}{} & \multicolumn{2}{l|}{ Regular verb: cantar } & \multicolumn{2}{l|}{ Irregular verb: ir } \\
\cline { 2 - 5 } & $\begin{array}{l}\text { Inflected } \\
\text { Infin. }\end{array}$ & $\begin{array}{l}\text { Future } \\
\text { Subjunctive }\end{array}$ & $\begin{array}{l}\text { Inflected } \\
\text { Infin. }\end{array}$ & $\begin{array}{l}\text { Future } \\
\text { Subjunctive }\end{array}$ \\
\hline Eu & Cantar & Cantar & ir & for \\
Tu & cantares & cantares & ires & fores \\
Nós & cantarmos & cantarmos & irmos & formos \\
Vocês & cantarem & cantarem & irem & forem \\
Eles & cantarem & cantarem & irem & forem \\
\hline
\end{tabular}

Thus, in the case of the verb ir, the inflected infinitival form for the $1 \mathrm{PL}$, for instance, is irmos, whereas the future subjunctive is formos. In view of the attested cases of agreement leveling in the future subjunctive, we included if and when clauses in our GJT and we varied the use of regular and irregular verbs as controlled variables.

In each condition, there were first person plural (1PL) and third person plural (3PL) subjects; in the case of 3PL, we alternated between the use of a pronoun and a full DP. 


\section{Procedure}

The test was presented to the study group in a face-to-face session and participants were confronted with 120 randomly distributed items, corresponding to the conditions under study. After reading each sentence, participants had to position themselves according to the following Likert scale: 'totally accept', 'accept', 'hard to accept' and 'totally reject'. This scale lacks a neutral point, so as to force the subjects to take a clear stand on the issue.

\section{Results}

We were able to observe that there is an expressive difference in the grammaticality judgments concerning non-standard forms of infinitival clauses $(56.2 \%$, Standard Deviation $(S D)=20.3)$ and finite clauses $(22.7 \%, \mathrm{SD}=21.1)$, as presented in Graph 1.

\section{GRAPH 1}

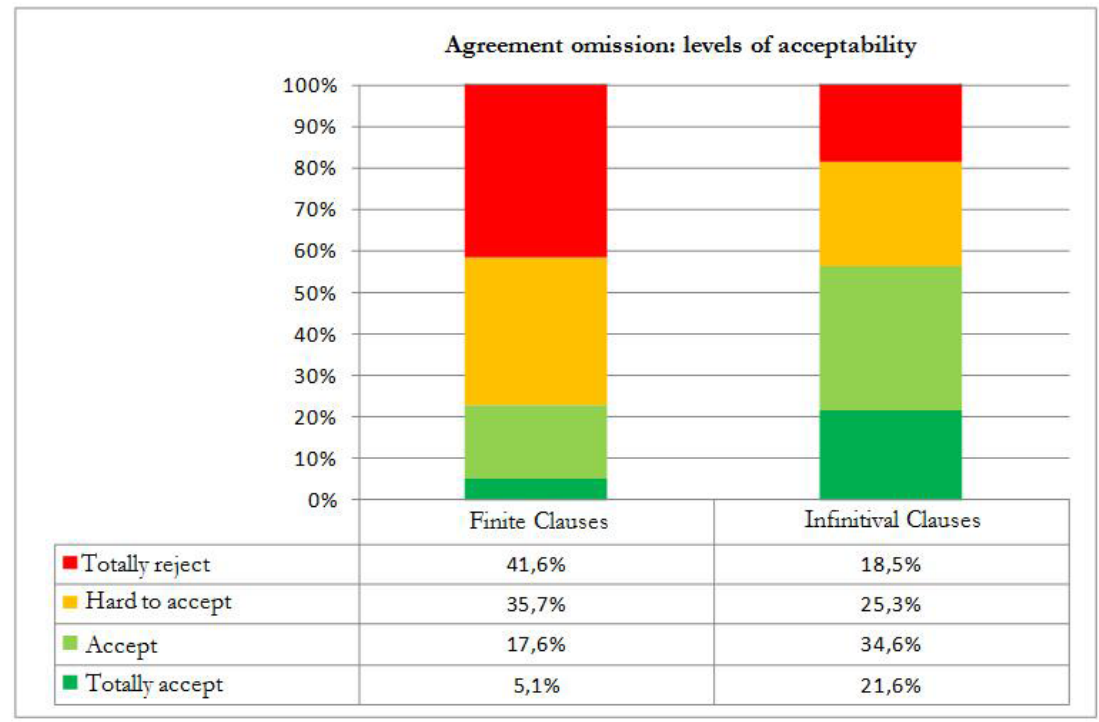


To check for statistically significant differences, we applied a T-Test for Paired Samples, as presented in Table 1.

\section{TABLE 1}

\begin{tabular}{llll}
\hline & Finite clauses \\
& $\begin{array}{l}\text { Infinitival Clauses } \\
\text { Mean }(S D)\end{array}$ & $\begin{array}{l}\mathrm{N}=50) \\
\text { Mean }(S D)\end{array}$ & $t(49)$ \\
\hline Study group & $22.7(21.1)$ & $56.2(20.3)$ & $13.45^{* * *}$ \\
\hline
\end{tabular}

$* * * p<.001$

As shown, there are significant differences between the levels of acceptability of finite and infinitival clauses without verbal agreement: $t$ $(49)=13.45, \mathrm{p}<.001$. The results concerning the clauses in the future subjunctive aren't included in these calculations because they were very similar to those of the infinitival clauses. Later, we will return to the future subjunctive. For now, we focus on infinitival clauses.

Graph 2 shows the rates of the levels of acceptability in clauses with and without verbal agreement:

\section{GRAPH 2}

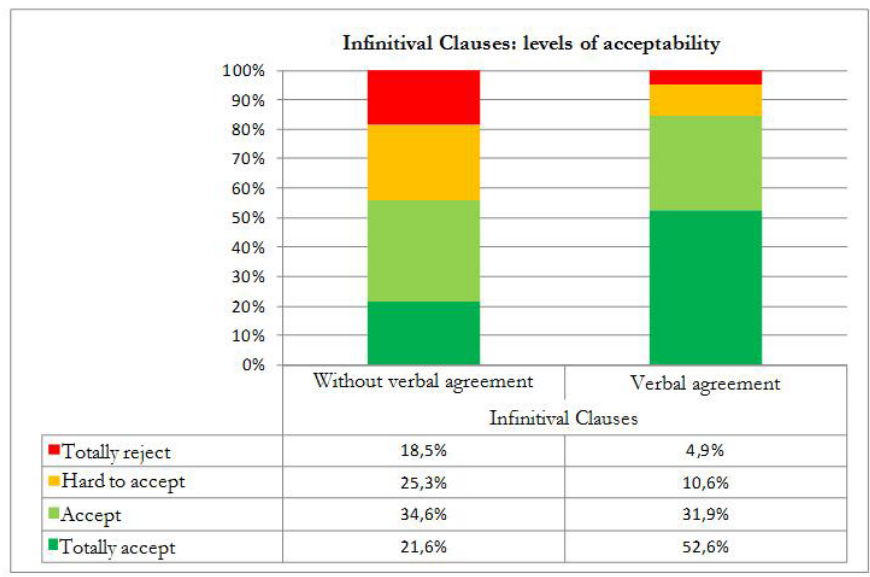


In spite of the difference in percentage (28.3\%), speakers accept both standard verbal agreement $(84.5 \%, \mathrm{SD}=9.2)$ and non-standard verbal agreement $(56.2 \%, \mathrm{SD}=20.3)$. To check for statistically significant differences, we applied a T-Test for Paired Samples as presented in Table 2.

TABLE 2

\begin{tabular}{llll}
\hline & $\begin{array}{l}\text { Verbal } \\
\text { agreement } \\
(\mathrm{N}=50) \\
\text { Mean (SD) }\end{array}$ & $\begin{array}{l}\text { Without Verbal } \\
\text { agreement } \\
(\mathrm{N}=50) \\
\text { Mean }(S D)\end{array}$ & $t(49)$ \\
\hline $\begin{array}{l}\text { Study } \\
\text { group }\end{array}$ & $56.2(20.3)$ & $84.5(9.2)$ & $10.23^{* * *}$ \\
$* * * p<.001$ & & & \\
\hline
\end{tabular}

The results show that there are significant differences between the levels of acceptability of infinitival clauses with and without verbal agreement: $\mathrm{t}(49)=10,23, \mathrm{p}<.001$. Despite this statistical result, the fact remains that $56.2 \%$ of the infinitival clauses without verbal agreement were accepted by the participants.

Graph 3 presents the levels of acceptability per context of nonstandard verbal agreement in infinitival clauses. 


\section{GRAPH 3}

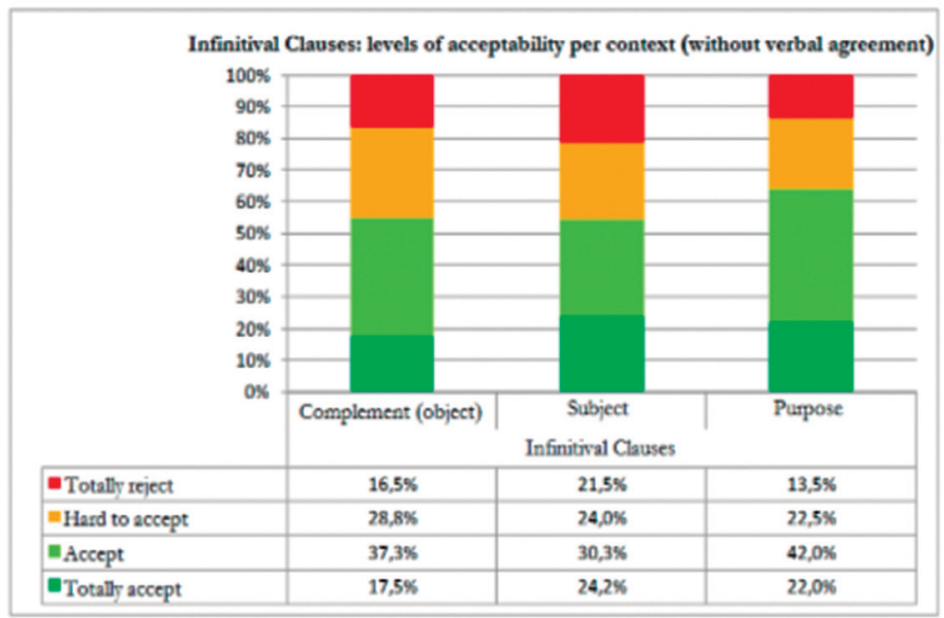

Graph 3 shows that the context with the highest level of acceptability corresponds to infinitival purpose clauses $(64 \%, \mathrm{SD}=33.9)$. The following example is illustrative:

Standard: comermos

(10) A mãe faz sempre pão para nós comer. the mother makes always bread for we eat.INF.Ø 'Mother always makes bread for us to eat.'

We note that the highest percentage of acceptance in purpose clauses is not related to exceptional case marking (ECM). This possibility was safeguarded in the design of the test itself by including examples in which the embedded subject appears in the oblique case:

(11) *A mãe faz sempre pão para mim comer. the mother makes always bread for me.oBL eat.INF. $\varnothing$ 
Our participants overwhelmingly rejected examples such as (11) (95.5\% of non-acceptance) while accepting the corresponding sentences with a nominative pronoun (see graph 4):

(12) A mãe faz sempre pão para eu comer. the mother makes always bread for I.NOM eat.INF. $\varnothing$ 'Mother always cooks bread for me to eat.'

\section{GRAPH 4}

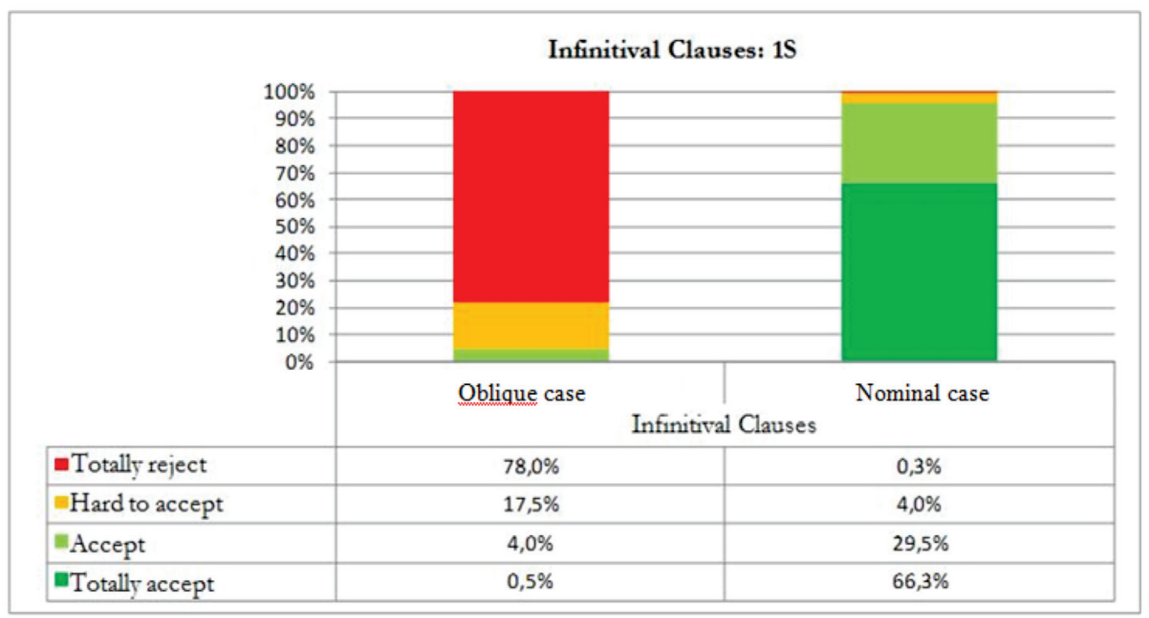

Coming back to the results presented in Graph 3, it appears that the argumental clauses in subject and object position show very similar results $(54.8 \%(\mathrm{SD}=23.4)$ and $54.5 \%(\mathrm{SD}=21.2)$, respectively). Subject clauses selected by adjectival predicates (cf. (13)) were accepted in 49.5\% of the cases (again, the asterisk reflects our own judgements). 
(13) *É difícil nós trabalhar assim. Standard: trabalharmos

Is difficult we work.INF.Ø like.this

'It is difficult for us to work like this.'

In spite of the differences among different types of infinitival clauses, the results for the infinitival clauses lead to the conclusion that, in fact, in this region, speakers accept variation in verbal agreement.

Now we turn to finite clauses. As mentioned before, the levels of acceptability in finite clauses are very low $(22.7 \%, \mathrm{SD}=21.1)$. Next we discuss these in more detail. It should be noted that these results exclude contexts with the future subjunctive (Graph 5).

\section{GRAPH 5}

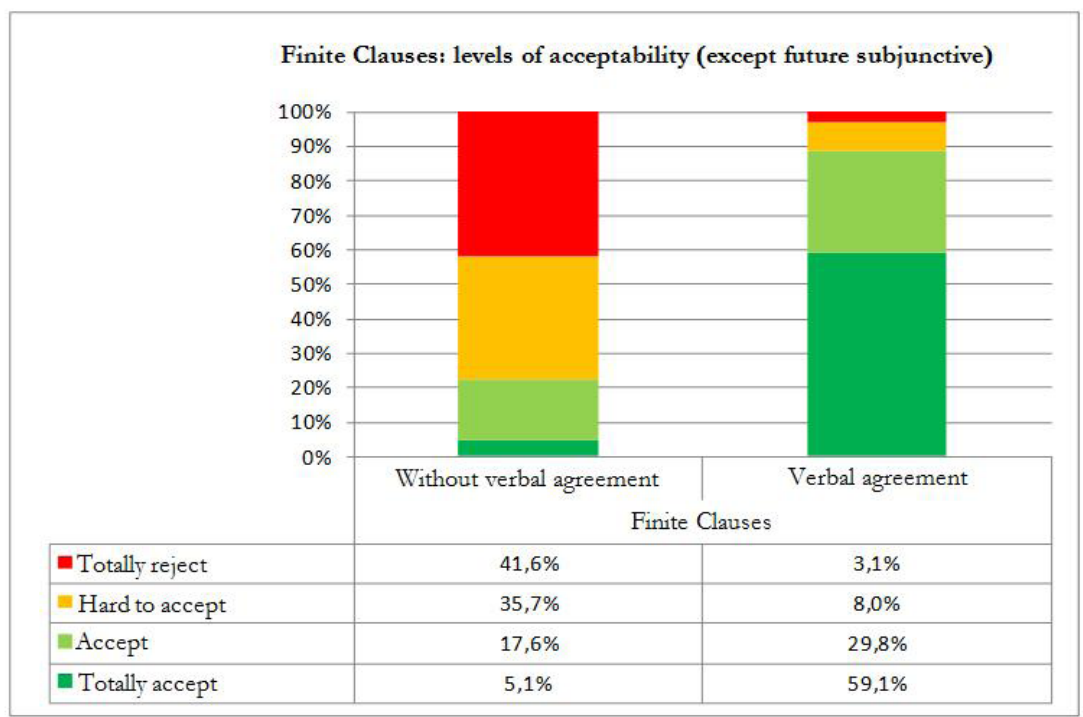

Graph 6 presents the acceptability rates for finite sentences without verbal agreement distributed per context. This graph includes the results for the future subjunctive. 
GRAPH 6

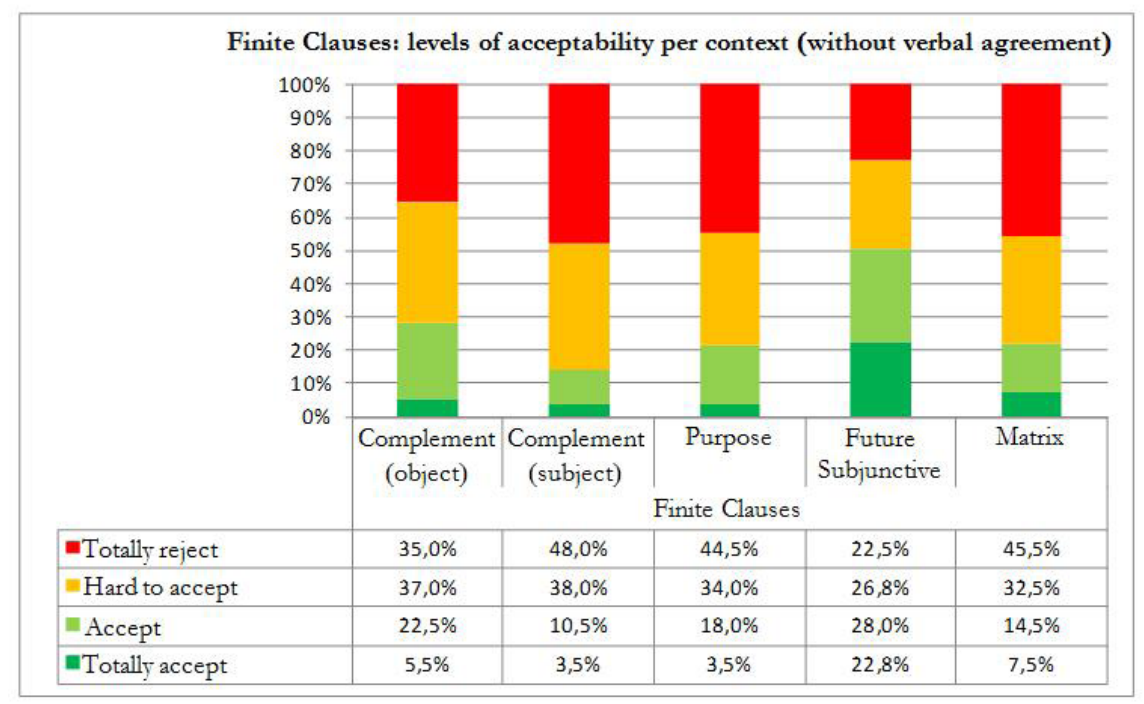

In Graph 6 the results for the future subjunctive stand out, as mentioned before. The subjects clearly do not accept the remaining contexts without verbal agreement but accept those with the future subjunctive (50.8\%, SD=28.4): 53\% of acceptance for regular verbs and $48.5 \%$ for the irregular ones. The results in this context are, therefore, very similar to those of infinitival clauses with non-standard verbal agreement $(56.2 \%, \mathrm{SD}=20.3)$. To check whether there was any statistical difference between the levels of acceptance of the future subjunctive without verbal agreement and other finite clauses, also without verbal agreement, we applied a T-Test for Paired Samples (Table 4). 
TABLE 4

\begin{tabular}{lccc}
\hline & $\begin{array}{c}\text { Future } \\
\text { subjunctive } \\
(\mathrm{N}=50)\end{array}$ & $\begin{array}{c}\text { Other Finite clauses } \\
(\mathrm{N}=50)\end{array}$ & \\
& Mean $(S D)$ & Mean $(S D)$ & $t(49)$ \\
\hline $\begin{array}{l}\text { Study } \\
\text { group }\end{array}$ & $50.8(28.4)$ & $22.7(21.1)$ & $-9.15^{* * *}$ \\
\hline$* * * p<.001$ & & &
\end{tabular}

The results show that there are significant differences between the levels of acceptability of the future subjunctive and the other finite clauses: $\mathrm{t}(49)=-9.15, \mathrm{p}<.001$. Thus, we conclude that, in this dialect, the future subjunctive differs from the other finite contexts and displays a pattern that is similar to that of infinitival clauses.

\subsection{Grammaticality judgement test 2: control group}

So as to verify whether this type of non-standard agreement is geographically restricted, the same GJT was applied to Portuguese speakers from different districts from North to South of Portugal who have never lived in Vale do Sousa or Vale do Ave.

\section{Participants}

68 speakers from different districts from North to South of Portugal - Northern districts: Viana do Castelo, Braga, Porto, Vila Real, Aveiro, Coimbra; Central districts: Castelo Branco, Lisboa, Setúbal and Southern districts: Beja and Faro - who have never lived in Vale do Sousa or Vale do Ave. 


\section{Materials}

The same test applied to the study group.

\section{Procedure}

The same test, with the same items and the same instructions, was applied to the control group, the only difference being that this group was tested via the Internet, due to time and space constraints.

\section{Results}

The results were clear and allow us to conclude that these EP speakers do not accept the infinitival forms without agreement, unlike the study group. The results for standard agreement clauses are similar to those of the group of study. Graph 7 presents the results for the control group, excluding, for now, the future subjunctive.

\section{GRAPH 7}

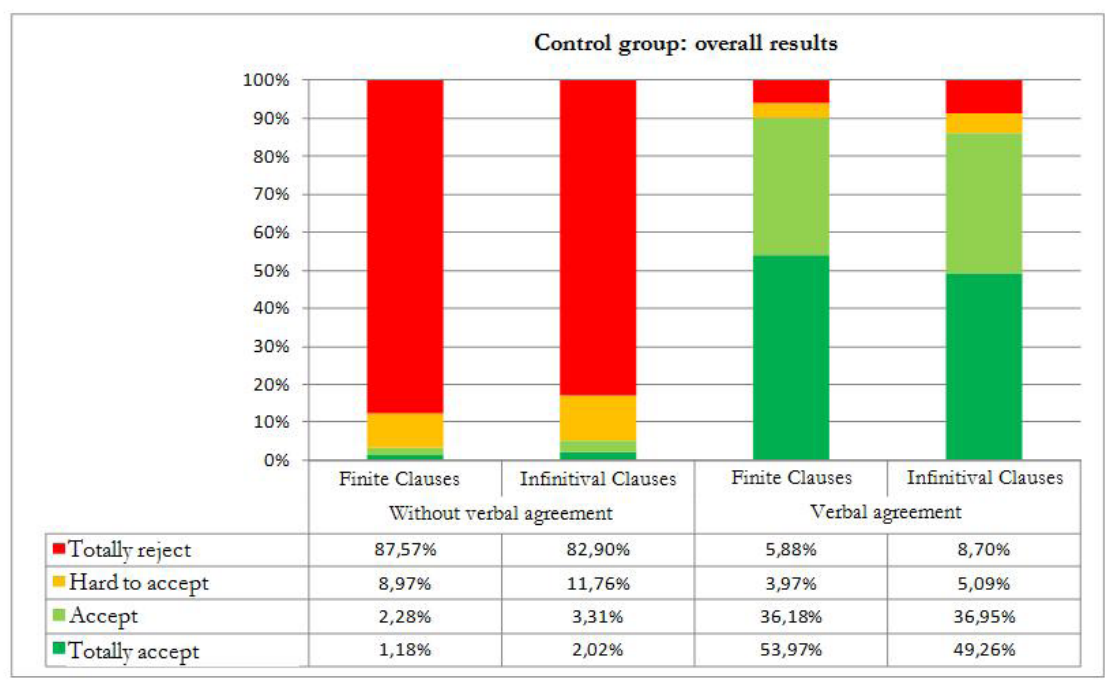


The speakers from the control group reject the clauses without verbal agreement, regardless of whether they are infinitival $(94.66 \%, \mathrm{SD}=16.2)$ or finite clauses $(96.54 \%, \mathrm{SD}=12.6)$. Similar results were obtained in the future subjunctive $(95.78 \%, \mathrm{SD}=13.8)$, as seen in Graph 8:

\section{GRAPH 8}

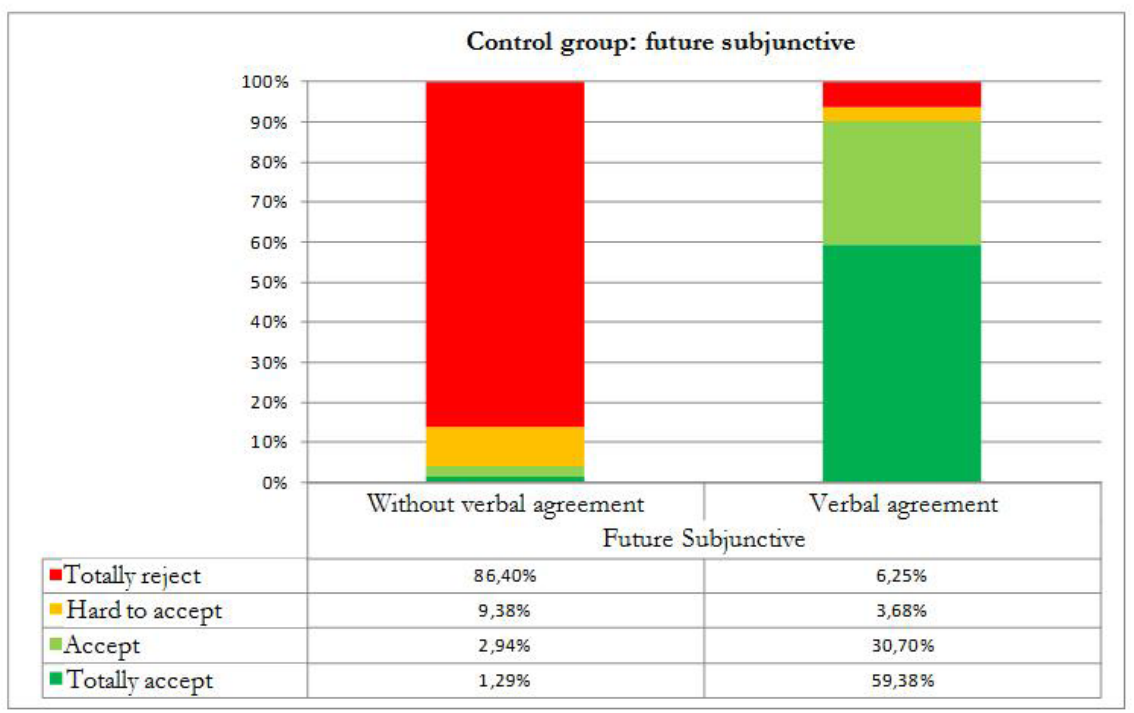

\subsection{Discussion}

The data collected from both groups in the GJT enable us to conclude that, in fact, the speakers of the group of study cancel agreement even when the syntactic structure provides all the information for them to establish it. In this regard, EP speakers present a linguistic behavior that is similar to that of non-standard varieties of Brazilian Portuguese (cf. (1)), with one crucial difference: in the former case, agreement leveling is limited to contexts in which the verb is either in the inflected infinitive or in the future of subjunctive. In addition, it has also been confirmed that this pattern is indeed limited to a particular region of Portugal, namely Vale do Sousa and Vale do Ave. 


\subsection{Self-paced reading test}

\section{Participants}

The same participants from Experiment 1.

\section{Materials}

120 random items, corresponding to the conditions under study, 8 sentences for each of the 15 conditions.

\section{Procedure}

The self paced reading test was applied to the participants of the study group in a face-to-face session using Linger, a computer application that allows the realization of a wide range of experiences related to language processing. This type of test determines the reading time of each participant in each of the regions of the sentence, both critical (segments under study) and noncritical (remaining segments of the sentence) and, based on these reading times, it is possible to assess if the critical segments took more or less time to process.

Each participant was responsible for revealing, at a natural reading pace, a sentence that appeared on the screen, word by word, as the participant pressed a key. At the end of each sentence, participants were faced with a question, which appeared at once on the screen. Participants should press a key for 'yes' and another key for 'no'. They were encouraged to read the sentences at a natural pace and to answer the questions as accurately as possible; they were never informed that there would be non-standard agreement items in the test.

\section{Predictions}

Our expectations were the following: (i) clauses with standard verbal agreement would be read faster than the others; (ii) the infinitival 
structures without agreement and the structures in the future subjunctive without agreement would be processed faster than the structures without agreement in other tenses.

\section{Results}

For the purposes of the analysis, we only considered the participants who responded correctly to more than two-thirds of the questions as well as the participants whose average individual reading time did not deviate from the overall average 2.5 standard deviations. In the end, no participant was excluded. Results were analyzed according to the average reading time per character as the study examines critical segments with inherently different extensions, i.e., "comer" versus "comermos" or "comerem"; "ir" versus "irmos" or "irem".

Table 5 presents the average reading times per character in each of the study conditions.

\section{TABLE 5}

\section{Conditions}

Average reading time

per character (ms)

Standard verbal agreement

Finite Clauses (excluding Future Subjunctive) $\quad 59.85$

Infinitival Clauses

Future Subjunctive

Non-standard verbal agreement

Finite Clauses (excluding Future Subjunctive) $\quad 71.20$

Infinitival Clauses

96.70

Future Subjunctive

106.85

The data presented correspond to the average reading times per character for all participants at the critical segments. 


\section{Discussion}

As expected, on average, clauses with standard agreement are read much faster than those with nonstandard agreement. Regarding the latter, the expected result was that subjects would read the infinitival and future subjunctive clauses faster than the others. However, this is not what happened. We got the opposite result: the infinitive and the future subjunctive structures with nonstandard agreement took longer reading times $(96,70 \mathrm{~ms}$ and $106.85 \mathrm{~ms}$, respectively) than the other clauses $(71.20 \mathrm{~ms})$.

Even though the reading times for the nonstandard agreement cases went in the opposite direction from what was predicted, we observe that the inflected infinitive and the future subjunctive constructions display a pattern that sets them apart from the other finite clauses: they evidence longer reading times not only in the nonstandard agreement cases but also in the standard agreement ones. In the latter case, the future subjunctive clauses are those that present longer reading times $(73.27 \mathrm{~ms})$, but these results are closer to those obtained for the infinitival clauses with standard verbal agreement $(65.48 \mathrm{~ms})$ than to those of the other finite clauses $(59,85 \mathrm{~ms})$. Moreover, in the nonstandard agreement constructions, the values obtained for the inflected infinitive $(96.70 \mathrm{~ms})$ and the future subjunctive $(106.85 \mathrm{~ms})$ are the closest values found when the average reading times for all conditions are compared.

In sum, the results of the self-paced reading test suggest that, overall, the future subjunctive and the inflected infinitive demand higher, albeit similar, processing costs than the other conditions under study. Our take on this issue is that this is due precisely to the presence of two variants in the grammar of these speakers - one variant with full agreement inflection and the other with non-standard agreement inflection. By hypothesis, this situation imposes additional processing costs. This hypothesis is supported by the following facts: (1) the reading times obtained for infinitival and future subjunctive clauses with standard 
verbal agreement are considerably higher than those obtained with their counterparts with other finite tenses; (2) infinitival clauses and future subjunctive clauses without verbal agreement present closer reading times than any other conditions ${ }^{1}$.

\subsection{Interim summary}

Combining the results of the self-paced reading tests with those of the GJT, we conclude that agreement leveling in the future subjunctive and in the infinitive is indeed an option that is available in the grammar of our subjects.

At this point, two questions arise:

1. Does neutralization apply to Person as well as Number or just to Number? In the tests applied thus far, the persons used were $1 \mathrm{P}$ and $3 \mathrm{P}$ plural, so in order to determine whether Person is affected, we need to test for $2 \mathrm{P}$ singular.

2. Does leveling also apply in cases of subject drop? According to A. RODRIGUES (2004), one of the causes of agreement leveling in BP in the presence of an overt subject is the fact that the information is redundant: the phi-feature set present in verbal agreement reduplicates the phi-features of the subject. If this functional principle applies to the speakers in this study, it is anticipated that speakers will reject sentences displaying null subjects and lack of agreement.

In order to tackle these two issues, we ran two further GJTs. These are described in the next section.

\subsection{Grammaticality Judgement Test 3}

So as to determine whether agreement leveling affects Person, a new

\footnotetext{
${ }^{1}$ One way of testing this hypothesis would be to apply the same self-paced reading test to a control group. So far, we were not able to undertake this task and leave it for future research.
} 
GJT was applied to the same participants. In this second test, sentences with $2 \mathrm{sG}$ were included.

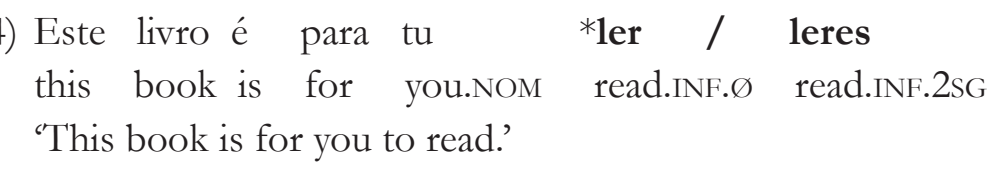

If neutralization affects Person, omission of agreement in $2 \mathrm{P}$ should exhibit levels of acceptability comparable to those observed with omission of agreement in the plural forms. We opted for $2 \mathrm{sG}$ instead of 2PL especially because the 2PL form vós, 'you' is disappearing, particularly among younger speakers, being replaced by the form vocês, which triggers 3P verbal agreement. Many speakers who still retain the pronoun vós often find it difficult to conjugate the verb in 2PL, so this variable would introduce unnecessary "noise" in analyzing the results.

\section{Participants}

The same participants from Experiment1.

\section{Materials}

42 random items, corresponding to the conditions under study

\section{Procedure}

The same procedure as in Experiment 1.

\section{Results}

In Graph 9, we present the results of this second grammaticality judgment task with respect to omission of 2SG agreement morphology (right column) in comparison with omission of 1PL and 3PL agreement morphology (left column) in infinitival clauses. 


\section{GRAPH 9}

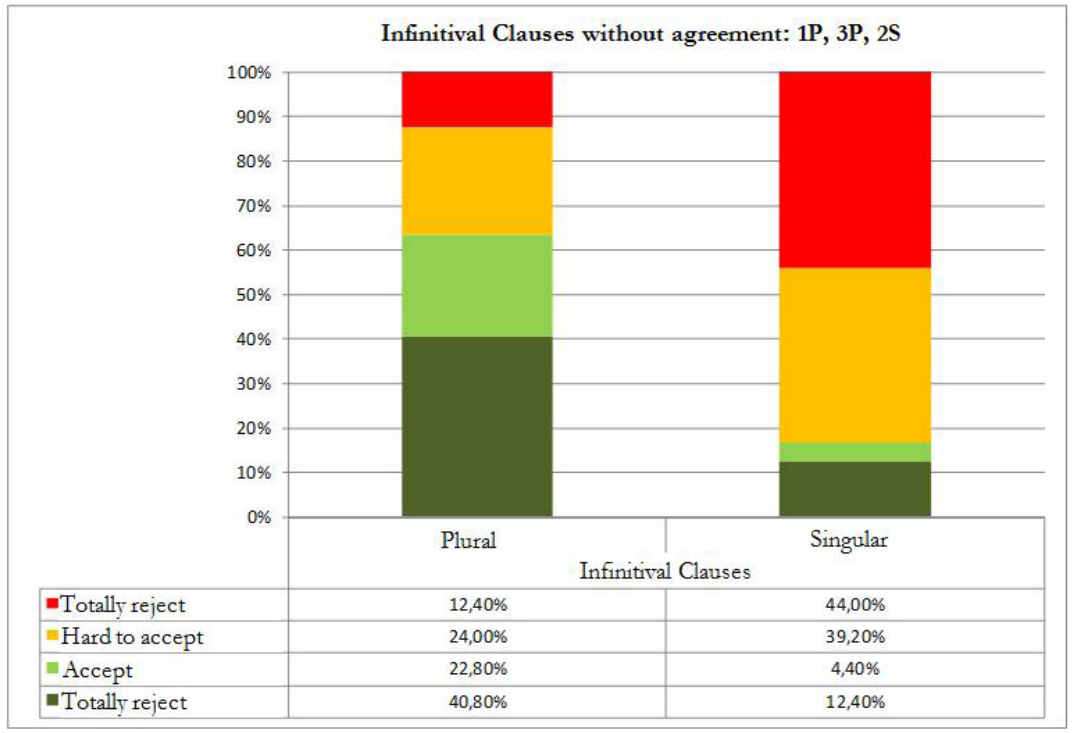

Note that the level of acceptance of infinitival clauses without agreement in $1 \mathrm{PL}$ and $3 \mathrm{PL}$ is again high $(63.6 \%)$. In contrast, the results of clauses with $2 \mathrm{~S}_{\mathrm{G}}$ show that speakers do not accept this structure $(83.2 \%)$ and do not recognize it as part of their grammar. Hence the conclusion is clear: the $2 \mathrm{SG}_{\mathrm{G}}$ is not affected by neutralization. We take this observation as an indication that Number is the feature that is targeted by neutralization, rather than Person.

\subsection{Grammaticality judgement test 4}

The third GJT aimed to determine whether agreement leveling also occurs in null subject structures. On the assumption that the presence of overt agreement morphology is a prerequisite for subject pro-drop in a null subject language of the consistent type like EP, the prediction is that agreement omission should yield deviant results when the subject is null. This cannot be tested in infinitives in view of the existence of noninflected infinitives, which lack agreement morphology, but it can be 
tested in the future subjunctive. Therefore, this GJT contained examples with the future subjunctive in addition to matrix finite clauses.

The two versions, with and without agreement, were presented to the subjects (the version without agreement is ungrammatical in standard $\mathrm{EP})$ :

a. Eles querem sair mais cedo. Se trabalhar, they want to leave earlier if work.SUBJ.FuT.ø, vão sair mais cedo.

go. IND.PRES.IPL leave earlier.

'They want to leave earlier. If they work, they will leave earlier.'

b. Eles vão chegar atrasados. Se trabalharem, they want to leave earlier if work.SUBJ.FUT.3PL, vão sair mais cedo.

go. IND.PRES.IPL leave earlier.

\section{Participants}

The same participants from Experiment 1.

\section{Materials}

40 random items, corresponding to the conditions under study

\section{Procedure}

The same procedure as in Experiment 1.

\section{Results}

Regarding matrix clauses, the results were as predicted: the participants accepted the clauses with standard verbal agreement $(93.5 \%)$ and rejected the structures without agreement with only $12.5 \%$ 
acceptance. The results for the future subjunctive in null subject clauses are shown in Graph 10.

\section{GRAPH 10}

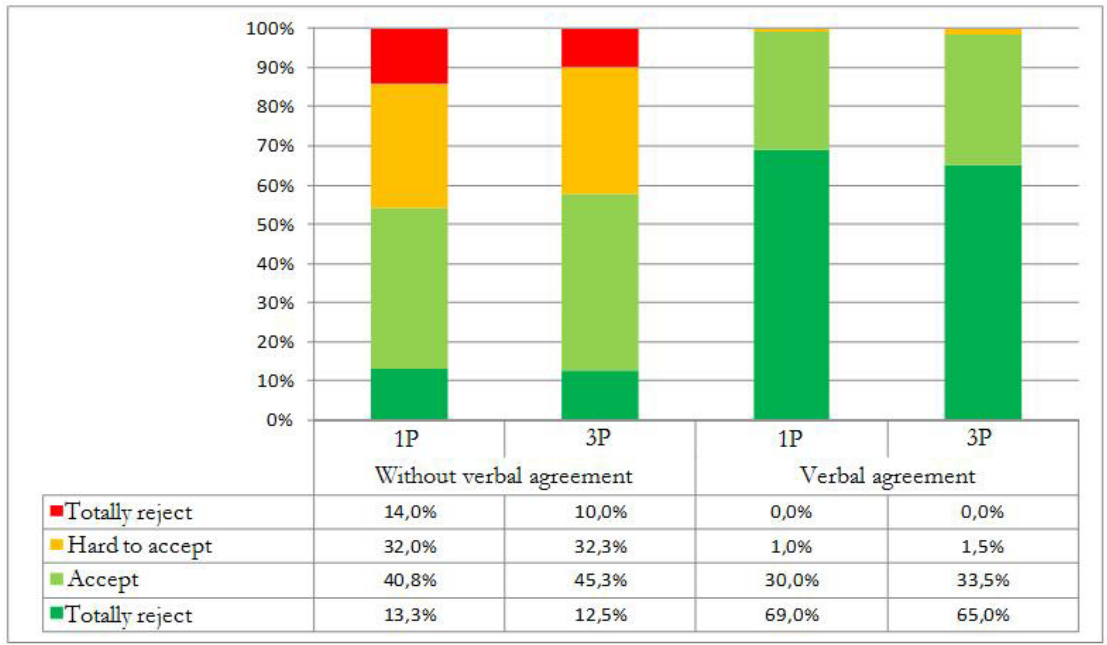

In the cases of null subject constructions, the participants accept unequivocally the structures with verbal agreement, as expected, regardless of which plural person is omitted $(99.0 \%$ and $98.5 \%$ in $1 \mathrm{P}$ and 3P, respectively); but there are also high levels of acceptance in structures without verbal agreement $(54.1 \%$ and $57.8 \%, 1 \mathrm{P}$ and $3 \mathrm{P}$, respectively), a joint average of $55.9 \%$.

\section{Discussion}

In view of the high levels of acceptance of structures without verbal agreement, we conclude that the data do not meet the initial prediction. The results of this test are particularly interesting when compared with those of the first test, with the same structures, but with overt subjects. 
When comparing the data, the levels of acceptance are very identical (cf. Table 2). This is a strong indicator that, for these speakers, agreement is also variable when the subject is null. In other words, the phenomenon in question doesn't interfere with a core syntactic property such as the licensing of a null subject.

TABLE 6

\section{Conditions}

Results

Future subjunctive clauses (without verbal agreement)

Overt subject

$91.8 \%$

Null subject

$98.8 \%$

Future subjunctive clauses (with verbal agreement)

Overt subject

$50.8 \%$

Null subject

$55.9 \%$

\subsection{Conclusions}

Summing up the results obtained thus far, the phenomenon of variable agreement under discussion has the following distinctive properties:

1. it occurs not only with infinitival forms but also in the future subjunctive;

2. it does not affect grammatical Person;

3. it doesn't interfere with the licensing of a null subject.

In our view, this cluster of properties is a strong indicator that the phenomenon in question is not purely syntactic and rather belongs with morphology. In the next section we propose an analysis of these facts that relies on the idea that agreement leveling is due to operations that take place in the post-syntactic PF branch of the grammar. 


\section{Analysis}

In this section, we present an analysis of the restricted kind of agreement leveling found in the grammars of the speakers of Vale do Ave and Vale do Sousa. However, before we present our analysis, we must provide an account of the standard dialect. We turn to this matter in the next subsection.

\subsection{The standard dialect}

We assume the model of Distributed Morphology (HALLE and MARANTZ1993,EMBICKandNOYER 2007).Distributed Morphology (DM) assumes a Morphological Structure (MS) level between Spell Out and PF. In this model, the output of narrow syntax is the input to MS, in which further operations apply during the computation to PF. DM is a "late insertion" model. The terminal nodes of the syntactic derivation — labeled morphemes - are bundles of abstract features relevant only to syntax and the phonological exponents for functional morphemes are inserted post-syntactically, via the process of Vocabulary Insertion (VI). The Vocabulary is a list of the phonological exponents of the different abstract morphemes of the language, paired with conditions of insertion (see below).

Following MARANTZ (1997), we take roots not to have any category; in the syntax they are merged with category-giving functional heads. In the verbal domain, this head is $v$ and is responsible for the verbal properties of the verbal complex, like (in)transitivity, agentivity, (accusative) case, and so on. Along the lines of OLTRA-MASSUET (1999) for Catalan, we assume that, in the unmarked case, the Tense (T), Mood (M), and Aspect (Asp) features are combined in EP into a single morpheme for the computational system. In the syntax, a root merges with the verbalizing head $v$ and further undergoes cyclic head-to-head movement all the way up to $\mathrm{T}$ (which stands for $\mathrm{T} / \mathrm{Asp} / \mathrm{M}$ or TAM for 
short). We further assume that, in a null subject language such as EP, $\mathrm{T}$ combines with an Agr node in the syntax, resulting in the following minimal representation for the verbal complex under Agr:

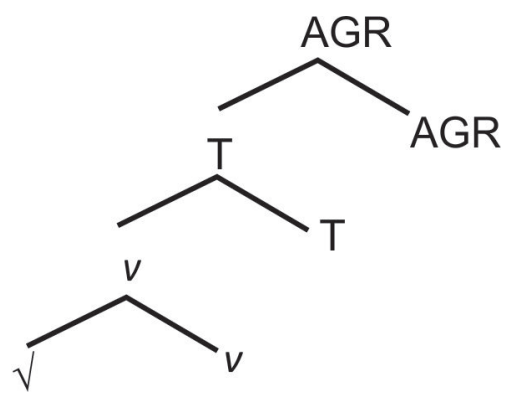

One further, fairly uncontroversial, assumption we make is that at MS $v$ has a theme vowel (Th) adjoined to it.

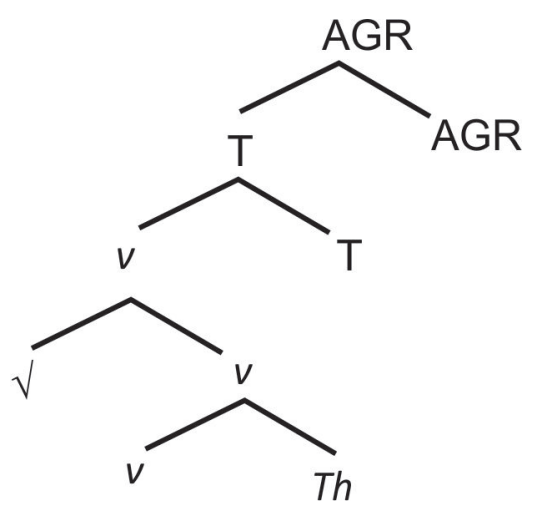

Th defines the class $v$ belongs to. In EP, there are three verb class features $\left(c_{1}, c_{2}, c_{3}\right)$ corresponding to the theme vowels $-a,-e,-i$, respectively ${ }^{2}$. ${ }^{2}$ OLTRA-MASSUET (1999) argues, on the basis of Catalan, that every functional head requires a (possibly null) theme vowel. However, since this issue is not crucial for 
In the case of infinitival clauses, we take $\mathrm{T}$ to be $[-\mathrm{FIN}]$, so the syntactic representation is as follows:

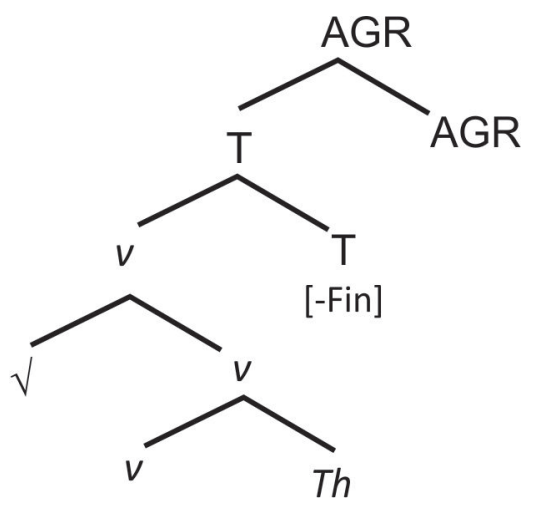

Regarding the future subjunctive of regular verbs, the features under T are [+Fin;+Fut; +Subj] (here we simply adapt OLTRA-MASSUET'S 1999 proposal for subjunctive clauses in Catalan):

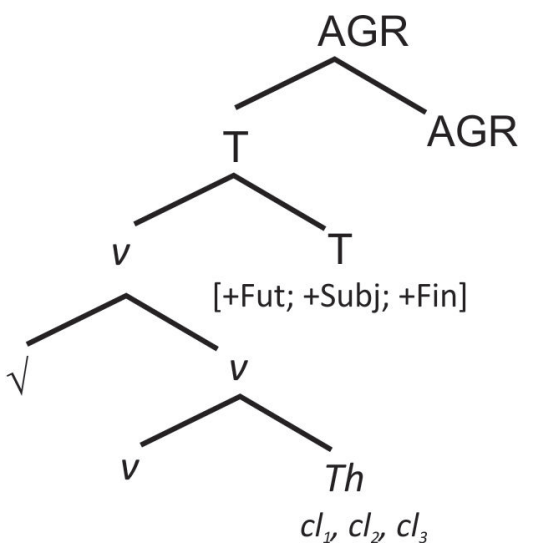

As for the phi-feature set to be inserted under Agr, we adopt NEVINS'S (2007) proposal according to which the feature matrices for person and number combine the following features:

the EP cases under discussion, we will not include the theme vowel under $\mathrm{T}$ in our representations. 
(20) phi-features for Person: [ \pm participant, \pm author $]$

Number features: $[ \pm \mathrm{pl}]$

The different combinations of phi-features give us the following specifications for the Agr node:

(21) 1Psg: [+participant; +author;-pl]

2Psg: [+participant; -author;-pl]

3Psg: [-participant; -pl]

1Ppl: [+participant; +author;+pl]

2Ppl: [+ participant; -author;+pl]

3Ppl: [-participant; +pl]

As mentioned above, in the PF component of the grammar, the functional morphemes receive phonological representations via VI where each Vocabulary Item is defined as a pair that specifies the relation between a phonological expression and a grammatical or semantic feature and possibly a context of insertion. We propose the following Vocabulary items for insertion under $T h$ (22), under $\mathrm{T}$ in infinitives and in the future subjunctive (23), and under Agr (24). The Vocabulary Items in (23) have actually been independently proposed by Oltra-Massuet (1999) in her analysis of Catalan verbal morphology. $/ \mathrm{r} /$ as an exponent for [+Fut] is needed also in the case of the future indicative (cf. Arregi and Oltra-Massuet 2005):

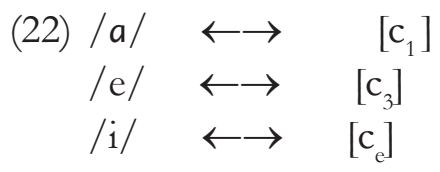


(23) $/ \mathrm{r} / \quad \leftarrow \quad[-$ Fin $]$

$/ \mathrm{r} / \quad \longleftrightarrow \quad[+\mathrm{Fut}]$

(24) $/ \mathrm{s} / \quad \longleftrightarrow \quad$ [+participant; -autor;-pl]

$/$ mos $/ \longleftrightarrow \quad[+$ participante; +autor; + pl $]$

$/ \mathrm{N} / \quad \longleftrightarrow \quad[+\mathrm{pl}]$

/ø/ $\longleftrightarrow$ elsewhere

One important feature of late insertion is underspecification, which is governed by the Subset Principle (HALLE 1997), that determines that Vocabulary Items do not need to be fully specified for insertion at a particular node:

(25) Subset Principle

The phonological exponent of a vocabulary item is inserted into a position if the item matches all or a subset of the features specified in that position. Insertion does not take place if the Vocabulary Item contains features not present in the morpheme.

The following Principle regulates competition among different Vocabulary Items capable of being inserted at a particular node:

(26) Blocking Principle

Whenever there is more than one Vocabulary Item capable of being inserted, the more specified item is to be chosen.

We can see how these two principles work when we consider the derivation of the form of the future subjunctive of a regular verb such as cantarmos. 
[Vkant- [ [c $]$ [ [+Fin; +Subj.; +Fut] [ [+participant; +author;+pl]]]]]

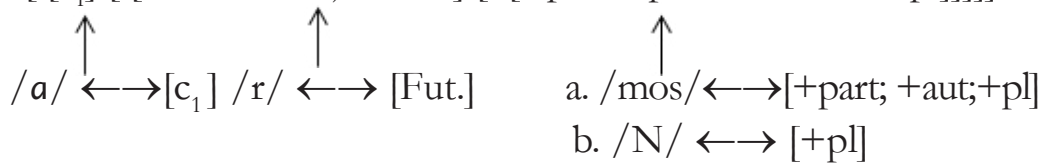

In this case, two exponents compete for insertion under Agr, /mos/ and / N/, but the Blocking Principle determines that the most specified one, $/ \mathrm{mos} /$, wins over the other. The representation in (27) yields the form / kantarmos/. For 3PL, there is only one form available, namely /N/. The form / kantareN/ is thus derived (I assume that a phonological rule inserts an epenthetic vowel before the nasal segment in order to create a possible rhyme).

In the case of regular verbs, the output forms for the inflected infinitive are homophonous with those of the future subjunctive. Where the two tenses diverge is with irregular verbs: in the first person plural we get irmos for the inflected infinitive and formos for the future subjunctive. For the purposes of this article, we will assume without further discussion, following standard practice in DM (MARANTZ, 1997), that stem allomorphy is obtained via application of phonological readjustment rules. Thus, in the case of the verb $i r$, a phonological readjustment rule spells out the structure $\left.\left[\mathrm{J}_{\mathrm{ir}}\right] \mathrm{th}\right]$ as $/ \mathrm{fo}^{\mathrm{f}} / \mathrm{in}$ the context of the Past and Future subjunctive. This stem combines with /-r/, the exponent for [Fut], yielding / for-/, and then further combines with the exponents for AGR. In the case of the 1PL, /mos/ combines with / for/ yielding formos. In the inflected infinitive, by contrast, there is no phonological readjustment, so the output form is irmos.

These derivations apply in the case of the standard dialect. In the next section we turn to agreement leveling in the dialect of Vale do Sousa and Vale do Ave. 


\subsection{Dialectal agreement leveling}

We propose that agreement leveling in the dialect under discussion is due to application of a rule of Impoverishment (Bonet 1991). Impoverishment rules apply in MS to morphosyntactic features (i.e., prior to VI) and eliminate certain distinctions. As a result, the Vocabulary Item that is expected to be chosen can no longer be inserted and a less specified item, generally the elsewhere case, is chosen instead; in other words, there is "retreat to the elsewhere case".

For the case in hand, we suggest a rule of Impoverishment that eliminates the Number feature from the morphemes that are positively specified for this feature, in a particular context. We will return shortly to the context of application of this rule.

\section{Impoverishment rule \\ $[+\mathrm{pl}] \rightarrow \quad[\varnothing] \quad / \quad\left[ \pm\right.$ participant; \pm author; $\left.\_\right]$}

As a corollary of (28), there is a retreat to the elsewhere case, which is the zero exponent.

As we have seen, (28) applies in two particular contexts: the inflected infinitive and the future subjunctive. When we consider what these two contexts have in common, the obvious answer is that they share the exponent, namely the lexical item /-r/. However, since Impoverishment applies before VI and manipulates abstract features, it is not possible to make reference to the exponent in the rule unless it is assumed that VI applies cyclically, from the most deeply embedded constituent outwards ${ }^{3}$. In fact, this claim has been forcefully put forward in BOBALIJK 2000 and has been assumed ever since in connection with contextual allomorphy (EMBICK 2010). In our case, Impoverishment at the Agr node must be able to "see" the particular lexical item that has been inserted under $\mathrm{T}$ in the immediate lower cycle.

\footnotetext{
${ }^{3}$ We thank Andrew Nevins for pointing out this fact to us, which turned out to be crucial.
} 
We restate the Impoverishment rule as follows:

(29) Impoverishment rule

$[+\mathrm{pl}] \rightarrow[\varnothing] /-\mathrm{r}]\left[_{\mathrm{Agr}} \pm\right.$ participant; \pm author; _ $]$

That Impoverishment is conditioned by the presence of the affix /-r/ follows from cyclicity and nothing else needs to be said.

Note, however, that rule (29) doesn't apply categorically in the dialect here described, given that the subjects accept both variants in the GJT (in fact, with a bias in favor of the standard variant). Even though our study didn't focus on production, it is a fact that speakers oscillate between the two variants, the one with and the one without paradigm leveling.

In the spirit of NEVINS and PARROT'T (2010), we propose that (29) is a variable rule in the Labovian sense, i.e., it is a rule the application of which is probabilistic rather than deterministic. Using the notion of "variable rule" taken from Variationist Sociolinguistics (LABOV, 1969; GUY, 1991) within the framework of DM, NEVINS and PARROT'T (2010) claim that variable Impoverishment is one of the mechanisms of inter and intra-individual variation in morphosyntax. Moreover, they claim that morphological Impoverishment operations are induced by the inherent and universal markedness of particular morphosyntactic features or their combinations, where the positive value of a morphosyntactic feature is considered marked (along the lines of GREENBERG, 1966; CROFT, 2003). The data discussed here is in line with this proposal given that the morphemes targeted by impoverishment are those that are positively specified for the Number feature $[+\mathrm{pl}]$ (see also OTRAMASSUET 2013 for a similar approach to variation in inflectional morphology in Catalan). 


\section{Conclusions}

This study started off from the observation that there is agreement leveling variation in particular syntactic environments in the speech of Vale do Sousa and Vale do Ave. We applied a series of GJ tests and a self paced reading task to a total of 50 speakers of this variety of Portuguese. The results from the tests allowed us to conclude that these speakers accept forms with and without overt agreement morphology in contexts with the inflected infinitive and the future subjunctive and reject the remaining finite sentences without agreement. It was also found that participants in the control group categorically reject the forms without agreement that are accepted by the participants in the study group. Moreover, the participants of the study group reject forms without agreement in contexts with the inflected infinitive and the future subjunctive in the 2PS, which suggests that it is Number that is being affected rather than Person.

The analysis proposed is based on the notion of 'variable Impoverishment' developed in NEVINS and PARROT'T (2010) as a means of explaining inter and intra-linguistic variation. To the extent that it succeeds in accounting for the data, this study may be seen as an argument in favor of the authors' suggestion of incorporating the notion of 'variable rule' of Variationist Sociolinguistics as a mechanism within the framework of DM. Thus, this study confirms the interest of applying the DM theoretical model to the study of intra-and interindividual variation in morphosyntax.

Yet another relevant finding of this study is the existence of an affinity between the inflected infinitive and the future subjunctive as opposed to all other grammatical tenses. Since what these two contexts have in common is the exponent itself, this is a case of inwards sensitive phonologically conditioned Impoverishment, as predicted in a model that assumes that VI proceeds cyclically, root-outwards (BOBALIJK 2000). 


\section{References}

ARREGI, Karlos; OLTRA-MASSUET, Isabel Stress-by-structure in Spanish. Linguistic Inquiry 36-1:43-84. 2005.

BARBOSA, Pilar; DUARTE, M. Eugênia; KATO, Mary. Null Subjects in European and Brazilian Portuguese. Journal of Portuguese Linguistics. 4, 11-52. Lisboa: Edições Colibri. 2005.

BASSANI, Indaiá de Santana; LUNGUINHO, Marcus Vinicius. Revisitando a flexão verbal do português à luz da Morfologia Distribuída: um estudo do presente, pretérito imperfeito e pretérito perfeito do indicativo. ReVEL, edição especial n. 5, 2011.

BONET, Eulàlia. Morphology after Syntax: Pronominal Clitics in Romance, MIT: Doctoral dissertation. 1991.

CARDOSO, A.; CARRILHO, E.; PEREIRA, S. On verbal agreement in European Portuguese: syntactic conditions for the $3 \mathrm{sg} / 3 \mathrm{pl}$ alternation. Diacrítica 25-1: 135-158. 2012.

DUARTE, M. I.; GONÇALVES A.; SANTOS. Control, tense and inflected infinitives: an argument for an Agree theory of Control. Manuscrito em fase de submissão, Universidade de Lisboa. 2013.

EMBICK, David; NOYER, Rolf. Distributed Morphology and the Syntax/Morphology Interface. In The Oxford Handbook of Linguistic Interfaces, Gillian Ramchand and Charles Reiss (eds.), 289-324. Oxford: Oxford University Press. 2007.

GREENBERG, Joseph. H. Language Universals with Special Reference to Feature Hierarchies. The Hage: Mouton. 1966. 
GUY, Gregory R. Explanation in variable phonology: An Exponential model of morphological constraints. Language Variation and Change 3: 1-22. 1991.

HALLE, Morris; MARANTZ, Alec Distributed Morphology and pieces of inflection. In: HALE, Ken; KEYSER, Samuel Jay. The View from Building 20. Cambridge, MA: MIT Press, pp. 111-176. 1993.

HALLE, Morris. Distributed Morphology: Impoverishment and Fission. MIT Working Papers in Linguistics. 1997.

LABOV, William. Contraction, deletion and inherent variability of the English copula. Language 45:715-762. 1969.

MARANTZ, Alec. No escape from syntax: Don't try morphological analysis in the privacy of your own lexicon. In Proceedings of the 21st Annual Penn Linguistics Colloquium, ed. A. Dimitriadis, et al., volume 4.2 of U. Penn Working Papers in Linguistics, 201-225. Penn Linguistics Club, University of Pennsylvania, Philadelphia. 1997.

MOTA, Maria Antónia; VIEIRA Sílvia. Contrastando variedades do português brasileiro e europeu: padrões de concordância sujeitoverbo. C. GONÇALVES and M. L. L. de ALMEIDA (orgs.) Lingua Portuguesa. Identidade, Difusão e Variabilidade. UFRJ, Pós-Graduação em Letras Vernáculas, pp. 87-113. 2008.

NEVINS, A. The representation of third person and its consequences for person-case effects. Natural Language and Linguistic Theory 25, 273-313. 2007.

NEVINS, Andrew; PARROTT, Jeffrey. Variable rules meet Impoverishment theory: Patterns of agreement leveling in English varieties. Lingua 120-5:1135-1159. 2010. 
OLTRA-MASSUET, Isabel. On the notion of theme vowel: a new approach to Catalan verbal morphology. Masters thesis. Cambridge, MA: MIT Press. 1999.

OLTRA-MASSUET, Isabel. Variability and allomorphy in the morphosyntax of Catalan past perfective. In Distributed Morphology Today - Morphemes for Morris Halle, Ora Matushanksy and Alec Marantz (eds.), pp.1-20. Cambridge, MA: Mass: MIT Press. 2013.

RODRIGUES, A. S. Concordância verbal, sociolinguística e história do português brasileiro. Forum Linguístico 4-1: 115-145. Florianópolis. 2004.

RODRIGUES, Cilene. Impoverished morphology and A-movement out of case-domains. University of Maryland. Ph.D diss. 2004.

SCHERRE, M. M. P. Aspectos da concordância de número no português do Brasil. Revista Internacional de Lingua Portuguesa (RILP) Norma e Variação do Português. Associação das Universidades de Língua Portuguesa. 12:37- 49. 1994.

SCHERRE, M. M .P.; NARO, A. J. Sobre a concordância de número no português falado do Brasil. In Ruffino, Giovanni (org.) Dialettologia, geolinguistica, sociolinguistica.(Atti del XXI Congresso Internazionale di Linguistica e Filologia Romanza) Centro di Studi Filologici e Linguistici Siciliani, Universitá di Palermo. Tübingen: Max Niemeyer Verlag, 5:509523. 1998. 